\title{
PRE-SERVICE ESL TEACHERS' PARTICIPATION IN A VIRTUAL COMMUNITY: A POSITIVE PSYCHOLOGY VIEW
}

\author{
Noraini Zulkepli ${ }^{1}$ \\ Faculty of Languages and Communication, \\ Universiti Pendidikan Sultan Idris (UPSI), Malaysia. \\ (Email: noraini@fbk.upsi.edu.my) \\ Siti Nor Amalina Ahmad Tajuddin² \\ Faculty of Languages and Communication \\ Universiti Pendidikan Sultan Idris (UPSI), Malaysia. \\ (Email: sitinoramalina@fbk.upsi.edu.my) \\ Intan Safinas Mohd Ariff AlBakri ${ }^{3}$ \\ Faculty of Languages and Communication \\ Universiti Pendidikan Sultan Idris (UPSI), Malaysia. \\ (Email: intan@ fbk.upsi.edu.my) \\ Azizah Atan ${ }^{4}$ \\ Faculty of Languages and Communication \\ Universiti Pendidikan Sultan Idris (UPSI), Malaysia. \\ (Email: azizah.atan@fbk.upsi.edu.my) \\ Rozana Mastura Abu Bakar ${ }^{5}$ \\ English Language Unit, Kelantan Matriculation College. \\ (Email: rozanamastura@kmkt.matrik.edu.my)
}

Received date: 13-08-2019

Revised date: 22-09-2019

Accepted date: 10-11-2019

Published date: 15-12-2019

To cite this document: Zulkepli, N., Tajuddin, S. N. A A., AlBakri, I. S. M. A., Atan, A. \& Abu Bakar, R. M. (2019). Pre-Service ESL Teachers' Participation in A Virtual Community: A Positive Psychology View. International Journal of Education, Psychology and Counseling, 4 (33), 122-131.

DOI: $10.35631 /$ IJEPC.4330010

\begin{abstract}
This qualitative research was carried out to investigate a group of pre-service ESL teachers' perceptions of their participation in a virtual community to facilitate their willingness to communicate. Positive Psychology was employed as the theoretical framework. Using the hybrid approach to analyse the findings, preliminary analysis revealed that the participants repeatedly mentioned the emergence of positive emotions. To understand better, a codebook based on Fredrickson's framework of positive emotion was developed to further analyse the data. Findings indicated that participation in a virtual community led to the emergence of four types of positive emotions: interest, hope, pride, and aspiration. This article provided some suggestions for teacher educators on the use of a virtual community to facilitate willingness to communicate.
\end{abstract}


Keywords: Pre-Service ESL Teachers, Willingness to Communicate (WTC), Virtual Community, Positive Psychology (PP), Positive Emotions, Hybrid Approach, Advanced ESL Learners

\section{Introduction}

Language Learning, be it in-class or out-of-class, is an emotionally loaded experience as it is often imbued with positive and negative feelings and experiences (Ross \& Starcke, 2016). Even though emotion is an important component in one's language learning process, it has not been given the attention that it deserves in the field of second language acquisition (SLA). Swain refers to the place of emotions in this field as "the elephants in the room- poorly studied, poorly understood, seen as inferior to rational thought (2013: 205).

In conceptualising the nature and relationship between emotion and cognition, Lantolf and Swain's (2019) discussion of the concept perezhevanie (Vygotsky 1926/1971, as cited in Lantolf and Swain, 2019) will be referred to. Perezhevanie is a Russian word which means 'experience' or 'lived experience'. It is how an individual emotionally reacts to a specific situation. In his theory of learning, Vygotsky postulates that perezhevanie (emotional experience) is an important component in learning as it motivates thinking. Ratner cautions against the polarisation of emotion and cognition, he asserts that "feelings and thinking are two sides of the same coin" (2000:6). To illustrate, in learning a language, a learner who conceives a particular learning situation as enjoyable will most likely learn the target language more effectively and successfully. This is because emotion is an integral part of a learning process as it impacts essential components of learning such as thinking, reasoning, and commitment (Lantolf \& Swain, 2019).

ESL practitioners have long been concerned about matters such as motivation, perseverance, as well as emotions; which are important for learners to sustain their efforts in the process of acquiring a second language that could often be long and full of challenges. For this reason, Positive Psychology (PP), a subfield in psychology, is now receiving recognition in the field of SLA (MacIntrye \& Mercer, 2014). The main goal of PP is to help individuals achieve better life. In SLA, there are several established constructs that could be categorised under PP such as: the humanistic approach to language teaching, the affective filter, and Dornyei's recent theory on motivation (MacIntrye \& Mercer, 2014). Dörnyei's (2005) L2 Motivational Self System consists of three core dimensions; ideal L2 self, ought-to L2 self and L2 learning experiences. The ideal L2 self can be defined as "the attributes that someone would ideally like to possess" (Dörnyei, 2010). The ought-to L2 self refers to the individual's attributes that should be possessed in favour of meeting obligations, responsibilities and duties towards the family and society (Dörnyei \& Chan, 2013). In relation to the present study, it could be said that the pre-service ESL teachers' ideal and ought-to selves are crucial in shaping their positive future goals and optimism in realising their fullest potentials to become effective and successful language teachers. One of the means to achieve this is by having a high sense of willingness to communicate (WTC).

WTC originated from the field of communication by scholars such as Burgoon (1976), and McCroskey and Baer (1985) (as cited in Zarrinabadi \& Tanbakooei, 2016); and it was not until about a decade later, WTC became an area of research in the field of L2 acquisition by scholars like MacIntyre and his associates. They conceptualise it as the probability of engaging in communication (i.e. speaking) when free to choose to do so (MacIntyre, Dörnyei, Clement \& 
Noels, 1998: 546). Past studies indicate that WTC are influenced by several factors such as motivation (Peng \& Woodrow, 2010; Peng, 2015) and emotions (Reinders \& Wattana, 2015). In their mixed methods study on the use of digital games to facilitate WTC, Reinders and Wattana (2015) conclude that this game-based learning is helpful in lowering learners' affective barriers in terms of speaking in the target language. Situated under the domain of PP, the present study seeks to investigate a group of pre-service ESL teachers' experiences as they participated in an online community with the intention to facilitate their WTC. Specifically, it addresses the following research question:

i. What types of positive emotions are invoked as they participated in the virtual community?

\section{The Study}

This paper is drawn from a mixed-methods research project investigating the effects of participation in a virtual community on a group of pre-service ESL teachers' willingness to communicate (WTC). In this study, participation in the virtual community refers to posting videos, viewing videos posted by others, commenting, and reading the comments given by their peers as well as the lecturers. The project was named "We Care". Facebook was chosen as the platform for the virtual community as in Malaysia, out of 24.6 million social networking users, 97.3 of them own a Facebook account (Malaysian Communications and Multimedia Commission, 2018). Other than the 18 research participants, three lecturers (two from the TESL Department and one from the Communication Department) were also members of the group. The project ran for five weeks, altogether 54 videos were posted in the group. Preliminary analysis of the qualitative data indicates that positive emotions evoke some salient responses from the participants. This resulted in the current article that focuses solely on positive emotions from a qualitative perspective.

\section{The Participants}

The participants were 18 pre-service ESL teachers at a local university. The purposive sampling was used where participants were selected based on their level of WTC. This was obtained from the survey that was done during the quantitative phase of the research. The selected participants had low level of WTC despite being advanced learners of English.

\section{Research Instruments}

The qualitative data were obtained from two research instruments: the participants' reflective notes and interviews.

\section{Reflective Notes}

The participants were contacted via WhatsApp. They were given several guided questions which they were asked to respond via the same application. The participants' responses in the reflective notes were probed further during the interview sessions.

\section{Interview}

The second stage of the qualitative data collection involved a series of interviews. The participants were given the flexibility either to attend the interview individually or with other participants. This flexibility was needed as the participants were having a week of study leave before the final examination thus many were occupied with doing revision and preparation for their summative assessments. 


\section{Data Analysis}

In this study, the qualitative analysis employed a hybrid approach where both the inductive and deductive thematic analyses were done (Fereday \& Muir-Cochrane, 2006). Firstly, data were analysed inductively where the data were coded based on units of meaning (Morehouse \& Maykut, 2002). The first stage of the analysis revealed that positive emotions were repeatedly mentioned by the participants as they described their experiences participating in the virtual community. In order to help illuminate the findings, the deductive technique was used where an analytical codebook was developed. This codebook was developed based on Frederick's categories of positive emotions (2013). Ensuring the applicability of the code to the raw findings (Boyatzis, 1998 as cited in Nowell, Norris, White, \& Moules, 2017) was an important step in the development of a codebook. To achieve this, a colleague was invited to code the interview data. The results were compared, and there were no changes required to the predetermined code template. This was then followed by identifying emerging themes where the isolated codes were brought together to identify a meaningful whole (Nowell et al., 2017).

\section{Results}

Results indicate that there are four types of positive emotions that are most frequently mentioned by the participants.

\section{Type 1: Interest}

This type of positive emotion refers to the feeling to explore and learn more in order to improve oneself. It emerges when a learner is confronted with a challenging, yet not overwhelming language learning situation.

In the present study, many participants felt the task given to them i.e. posting their personal videos speaking in English as a challenging language learning task. Nonetheless, after engaging in this task, some learners felt that is was not as overwhelming as they initially thought. Some learners talked about how this exercise helped increase their interest to do more as they believed that, to a certain extent, their confidence level has improved thus they were more willing to speak in English.

In Excerpt 1, the learner mentioned that she initially thought that others in the virtual community were better speakers of English as she normally saw them talking confidently in English. However, after viewing the videos posted by them, she found out that they also made some grammar mistakes. She used the phrase "in the same boat" to refer to this situation. This made her felt better about her own speaking abilities and she felt motivated thus created the interest in her to take part more in this speaking activity.

\section{Excerpt 1}

P2: Besides they are making mistakes in that video. So, I think "Oh, okay they are making mistakes maybe worse than me" and then but they are proud talking English. I feel like "Oh, they are just like in the same boat with me so why I'm afraid talking so at least it gives me some motivation because some people in this project, I didn't expect them to enter because I thought they are very good. Some of them are very good in talking and everything. So, when they enter this project, maybe they have the same feeling as me, they have some trouble and problem in talking English. 


\section{Excerpt 2}

P4: Because before this, I'm afraid like people will laugh at my English and whatever. But, after joined this project, I realise that not everyone knows English well.... Everyone is learning, so.... I thought with this project like..." Oh, everyone is not like have a excellent English". Everyone is.... maybe some of them are excellent, some of them are just same like me, so I can do better.

The following excerpt shows how a learner struggled with her confidence from the years during her Foundation study to the time when she joined the teacher education programme. However, taking part in this project where she got to view videos by others and read the comments given by other members of the virtual community as well as the lecturers involved, made her realise that when speaking, the audience were mainly keen to know the content and ideas; not so much on the use of language. Thus, it could be said that her involvement in the project has some positive effects on her confidence which led her to be interested to speak more in the target language.

\section{Excerpt 3}

P5: During foundation, there's a lot of people that can speak very clearly and there are......how to said....I'm very very scared because of them because they can talk very well and I can't do that because I feel fear for them. There are a lot...I...if I'm not mistaken there are about 500 something students and I think I'm the lowest one. So, when I moved to degree...TESL feel that everyone have a very good English and I feel scared to talk to with people because I feel... I think that they might think that I..." why she is being TESL... why she can't talk at all?". And then I thought that people will say that again and again so.... I'm very very afraid to talk with people in English because of that. But then when I take part in this activity, I come to my realization that actually people does not think about how we do, how well we do, how well we speak. People just want to hear what our opinion and then our experience. That's why I think that my confidence a little bit increases, and I need to speak more to improve.

\section{Type 2: Hope}

This type of positive emotion refers to the urge to employ one's language skills and capabilities in order to improve his or her mastery of the target language. It arises when a learner feels worried about his or her current language proficiency, and thus he or she hopes to improve.

In relation to the present study, though based on their MUET (Malaysian University English Test) results these pre-service teachers were considered as advanced users of English, they were still struggling with low confidence, thus affecting their WTC. Many reported feelings inferior compared to other peers whom they felt were better speakers of English. After participating in the virtual community, some learners expressed their hopes to enhance their WTC by engaging in activities that will help increase their communication confidence.

One learner felt hopeful and believed that the others in the group could give her the support. After viewing her friends' video, she felt more positive about herself and that she was also capable to be good in English.

Excerpt 1 
P6 : I mean when I first entered I thought maybe that the people who were in this group, those who weak in English but then I realise that everybody has that problem: the lack of confidence; not that we are weak in English...you just have to have a little help and it's okay to feel that because we're only human and when I see my friend speak in English, I think "okay if they can improve, I can also improve".

A learner admitted that she felt intimidated by her non-Malay friends whom she saw as proficient speakers of English to the extent that she avoided talking with them. However, when she started posting videos in the virtual community and viewing the videos posted by others, she become more hopeful of improving her speaking abilities as she realized that the others were also like her.

\section{Excerpt 2}

P7: Before this, non-Malay student tends to speak in English more than Malay language. So, I kind of avoided because I'm not really confident speaking English with them. From what I see, they are so proficient before this, but after I joined this project and have people see my video and I watched their videos, we are same level......so I can improve myself.

\section{Excerpt 3}

P8 : Because in real life, I feel a bit scared to speak in English although I'm taking tesl because I think my.....speaking in English little bit hard because in previous, I didn't speak much using English, so by doing the video, so I think it could help me to build the confidence because I speak only using the taking the video not in front of others so little bit help me.

\section{Excerpt 4}

P4: I feel like they are giving me support All of us in that....in this project is like happy each other and I really like the fact that.... Their comments are really.... Really motivate like "Oh, yes I need to try harder.... I need to try".

\section{Type 3: Pride}

Pride, another type of positive emotion, refers to feeling good about own achievement. In the context of the present study, it is about feeling good about one's ability to speak eloquently. This positive feeling emerges when the learner receives compliments from their peers and lecturers.

A majority of the learners, even though were recognized as advanced users of English, shared about how their struggle with a low sense of communication confidence which has a huge impact on their WTC. After participating in the virtual community, several learners reported how reading compliments from the lecturers have made them feel 'good' and 'happy' with their own speaking abilities. This has led to the emergence of the positive feeling of pride. This type of emotion can trigger one's self worth. In the context of the present study, it leads to an improved communication confidence that can facilitate an individual's WTC. 


\section{Excerpt 1}

P9: When I speak and then I received compliment and maybe that's why my confidence level is increased compare to before. To be specific, when I posted my video, I saw my friends commented and then the lecturer giving compliments... that increased my confident. Because, normally when we are presenting in class, the lecturer usually just comments on what we present not on our language. Maybe there's a mistake they will point out the mistakes but rarely give compliment on our speaking ability.

\section{Excerpt 2}

P3: When I received a compliment from the lecturer about my video, I felt like "wow if I speak, then people around me among the tesl they will feel happy" ....I think...for me...happy. That's what I feel.

\section{Excerpt 3}

P2: So, when I'm very proud, so I feel like "Oh, I'm not so bad actually" because they.... they post positive things, right? They said that "Okay, I have a good point in my video.....everything" so...I would think that "Okay, I'm not actually bad" because no matter...maybe some of my video, I have grammar mistakes, obvious one..maybe...but they still comment and compliment me so, maybe I think "Okay, it's alright to do grammar mistakes"...Yeah, it's normal if they compliment may but when lecturer compliment, may then and like and... you know... so I think "Okay, I'm approved, I like that".

P10: Especially there's a lot views or lot of likes....'Oh, okay, okay...people like what I'm talking about" so, yeah. I feel comfortable, satisfied. To get a good comment from a lecturer is really good because they are already fair level and also, they are encouraging us some more to post the videos and to talk in the video more...more. It feels great when a lecturer comments good.... something good to us. I have one comment from the lecturer she said the video is good, it means I did something good. I'm happy.

\section{Type 4: Inspiration}

This type of positive emotion emerges when a learner feels motivated to be as good as his or her peers who are proficient in the language.

Several learners reported feeling inspired by their peers who were able to speak confidently in the videos they posted in the virtual community. Words such as 'jealous', 'encouraged', 'motivated', and 'inspired' were used by the participants when they talked about how they felt after viewing videos by their peers.

\section{Excerpt 1}

P11: It help because I feel...sometime I feel jealous because they can talk better than me so, it...to be like them, I tend to speak a lot using English. 


\section{Excerpt 2}

P12: When I watched my friend's videos throughout the holiday I watch she post like 2 or 3 videos for the issue and about herself so I'm like.... I didn't think that she would be like that because she is really a quiet person. And very, she only with her circle. So, when she post a lot of video she was being really.... outspoken...open, yeah. So, I'm like "Wow! So, you are like that." So, because of that I'm like...she's very kind of motivated to be more like her.

\section{Excerpt 3}

P5: Okay, for me I saw a lot of video from Ashley. Ashley is the one posted the video. So, the first video I watched is Ashley. And then, when I saw her video, I think that "Oh, why does she have that confident level?" She actually inspired me to do more my video that's why I feel burden because she has very high confident level. So, it's actually inspired me to have a lot of story to tell people and I need to have high confident level, just like her. That's what I feel.

\section{Excerpt 4}

P5: I think the comments that were given to me or other people actually give us some idea in what we need to do in the future. And for example one of the lecturer's comments on my video, I feel very happy and I feel like "I want to do more on this because it's inspires me, make me feel....oh, people want to watch my video, people want to watch my story, I need do more, so that actually inspires me to do more in the future and have a high level confidence". Because when people comment like that, that means they watch us they know that we have confident level to speak. So, that inspires to have high confident level in the future.

\section{Discussion and Implication}

Findings reveal that their engagement in the virtual community has led to the emergence of four types of positive emotions: interest, hope, pride, and inspiration. Fredrickson's (2001) Broaden and Build theory proposes that positive emotions operate in five ways. First, it can broaden an individual's attention and thinking that leads to exploration and new learning. Second, it helps to remove negative feelings that one might have towards a particular situation or action. Third, it promotes resilience. Fourth it encourages building personal resources such - social bonds. Fifth, it promotes future well-being. In the context of the present study, it could be said that participation in the virtual community has helped, to a certain extent, the removal of negative feelings or to 'undo the lingering effects of negative feelings' (MacIntyre \& Gregersen, 2012: 197). Being in Malaysia where English is regarded as the second language and as pre-service ESL teachers, it could be said the participants have had vast experiences using English in their daily activities. These experiences, both positive and negative, have lasting effects on them. While positive emotions are facilitative to learning, the negative ones could be debilitating, and in the case of the present study lower one's WTC. Below is a discussion of how participation in a virtual community can help ESL learners to overcome their negative feelings.

Being a part of the virtual community has helped the participants realise that some peers whom they regarded as proficient speakers of English actually had problems with communication 
confidence as well, thus resulting in them (the proficient speakers) having a low level of WTC. One participant used the phrase "we were in the same boat" when she found out that others were also struggling with a similar issue i.e. unwilling to speak in English due to low communication confidence. This sense of realisation has led to the emergence of a positive feeling: hopeful. With this awareness, they became more optimistic about themselves as language learners.

The feedback given by their peers and the lecturers has helped them to feel positive about themselves as second language learners. Some learners claimed that reading the comments given by the lecturers made them feel good about their speaking abilities. Even though they were aware of the grammar mistakes that they made in the videos, the fact that the lecturers gave good comments has helped them to become aware that there is more to speaking rather than to worry about being structurally correct and accurate. Obtaining positive comments from both the lecturers and peers has led to the feeling of pride about oneself as a second language learner. In the context of the present study, this positive emotion is triggered by the compliments these learners received from their lecturers who were also members of the virtual community. Muris and Meesters (2014 as cited in Ross \& Stracke (2016) suggest that feeling proud of one's achievement foster a better sense of self-value and self-worth. In the present study, pride can lead to an increase in one's communication confidence and facilitate one's WTC.

This study has some implications for teacher educators. Findings indicate that participation in a virtual community have led to the emergence of some positive feelings which can facilitate their WTC. Dörnyei (2018) suggests group experience as one of the motivational strategies; where the focus is on group building techniques. These techniques involve strengthening the relationship among group members and creating opportunities for learners to learn from one another and interact among themselves. The group technique could be applicable to ESL preservice teachers since as a group they share a common desire to become members of proficient teachers of English. With this shared desire, they will be able to provide the needed emotional support that could help them go through the "struggle" in in-class and out-of-class environments. In line with technological advancements, ESL teacher educators can create such opportunities by building a virtual community for the teacher trainees such as forming a Facebook group where the trainees can share videos or live streaming of them using English, and comment on each other's videos. This out-of-class activity is beneficial for two reasons. First, by posting their videos and sharing their live streaming, the participants will have more opportunities to practise speaking the target language. A similar observation has been made by a study done by Ibrayeva and Fuller (2014) where it is suggested that learners are given more opportunities to use the language out-of-class. This will help to further enhance their language proficiency. Second, as mentioned earlier the virtual community can serve as a platform for them to encourage and emotionally support each other. This will help facilitate their WTC and motivate them to engage in sustained efforts to further improve their mastery of English.

\section{Acknowledgement}

This work was supported by University Research Grant Universiti Pendidikan Sultan Idris [Grant Reference Number: 2018-0012-107-01].

\section{References}

Dörnyei, Z. (2005). The psychology of the language learner: Individual differences in second language acquisition. London, UK: Lawrence Erlbaum. 
Dörnyei, Z. (2010). Questionnaires in second language research: Construction, administration, and processing (2nd ed.). New York: Routledge.

Dörnyei, Z. (2018). Motivating students and teachers. The TESOL encyclopedia of English language teaching, 1-6.

Dörnyei, Z., \& Chan, L. (2013). Motivation and vision: An analysis of future L2 self images, sensory styles, and imagery capacity across two target languages. Language learning, 63(3), 437-462.

Fereday, J., \& Muir-Cochrane, E. (2006). Demonstrating rigor using thematic analysis: A hybrid approach of inductive and deductive coding and theme development. International journal of qualitative methods, 5(1), 80-92.

Fredrickson, B. L. (2013). Positive emotions broaden and build. In Advances in experimental social psychology (Vol. 47, pp. 1-53). Academic Press.

Fredrickson, B. L. (2001). The role of positive emotions in positive psychology: The broaden and build theory of positive emotions. American Psychologist, 56(3), 218-226.

Ibrayeva, L., \& Fuller, C. (2014). The L2 motivational self system among Kazakh learners of LSP. The Asian ESP Journal, 1 (2), 40-63.

Lantolf, J. P., \& Swain, M. (2019). On the Emotion-Cognition Dialectic: A Sociocultural Response to Prior. The Modern Language Journal, 103(2), 528-530. In Classroomoriented research (pp. 19-37). Springer, Cham.

Malaysian Communications and Mulltimedia Commision (2018). Internet Users Survey 2018. Retrieved: $2^{\text {nd }}$ Oct,2019.

https://www.mcmc.gov.my/skmmgovmy/media/General/pdf/Internet-UsersSurvey-2018.pdf

MacIntyre, P. D., Dörnyei, Z., Clément, R., \& Noels, K. A. (1998). Conceptualizing willingness to communicate in a L2: A situational model of L2 confidence and affiliation. The Modern Language Journal, 82(4), 545-562.

MacIntyre, P., \& Gregersen, T. (2012). Affect: The role of language anxiety and other emotions in language learning. In Psychology for language learning (pp. 103-118). Palgrave Macmillan, London.

MacIntyre, P. D., \& Mercer, S. (2014). Introducing positive psychology to SLA. Studies in Second Language Learning and Teaching, 4(2), 153-172.

Morehouse, R. E., \& Maykut, P. (2002). Beginning qualitative research: A philosophical and practical guide. New York: Routledge.

Nowell, L. S., Norris, J. M., White, D. E., \& Moules, N. J. (2017). Thematic analysis: Striving to meet the trustworthiness criteria. International Journal of Qualitative Methods, 16(1), 1609406917733847.

Peng, J. E. (2015). L2 motivational self system, attitudes, and affect as predictors of L2 WTC: An imagined community perspective. The Asia-Pacific Education Researcher, 24(2), 433-443.

Peng, J. E., \& Woodrow, L. (2010). Willingness to communicate in English: A model in the Chinese EFL classroom context. Language learning, 60(4), 834-876.

Reinders, H., \& Wattana, S. (2015). Affect and willingness to communicate in digital gamebased learning. ReCALL, 27(1), 38-57.

Ross, A. S., \& Stracke, E. (2016). Learner perceptions and experiences of pride in second language education. Australian Review of Applied Linguistics, 39(3), 272-291.

Swain, M. (2013). The inseparability of cognition and emotion in second language learning. Language Teaching, 46(2), 195-207.

Zarrinabadi, N., \& Tanbakooei, N. (2016). Willingness to communicate: Rise, development, and some future directions. Language and Linguistics Compass, 10(1), 30-45. 